\title{
An Uber Ethical Dilemma: Examining the Social Issues at Stake
}

Florence Chee

Loyola University Chicago, fchee@luc.edu

Follow this and additional works at: https://ecommons.luc.edu/communication_facpubs

Part of the Applied Ethics Commons, and the Communication Commons

\section{Author Manuscript}

This is a pre-publication author manuscript of the final, published article.

\section{Recommended Citation}

Chee, Florence. An Uber Ethical Dilemma: Examining the Social Issues at Stake. Journal of Information, Communication and Ethics in Society, 16, 3: 16, 2018. Retrieved from Loyola eCommons, School of Communication: Faculty Publications and Other Works, http://dx.doi.org/10.1108/JICES-03-2018-0024

This Article is brought to you for free and open access by the Faculty Publications and Other Works by Department at Loyola eCommons. It has been accepted for inclusion in School of Communication: Faculty Publications and Other Works by an authorized administrator of Loyola eCommons. For more information, please contact ecommons@luc.edu.

\section{(c) $($ () $\ominus$}

This work is licensed under a Creative Commons Attribution-Noncommercial-No Derivative Works 3.0 License. (c) Emerald Publishing Limited 2018 


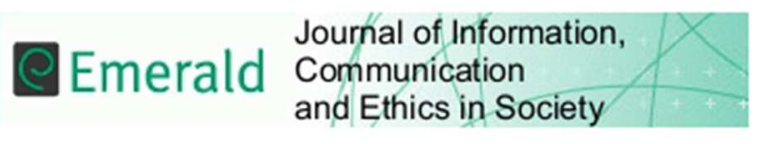

\title{
An Uber Ethical Dilemma: examining the social issues at stake
}

\begin{tabular}{|r|l|}
\hline Journal: & Journal of Information, Communication \& Ethics in Society \\
\hline Manuscript ID & Draft \\
\hline Manuscript Type: & Journal Paper \\
\hline Keywords: & Uber, Ethics, Digital, Policy \\
\hline
\end{tabular}

\author{
SCHOLARONE \\ Manuscripts
}




\title{
An Uber Ethical Dilemma: examining the social issues at stake
}

\author{
Introduction
}

This paper engages with the social issues emerging from the increasing reliance upon appdriven services as they pertain to precarious labor and ethical standpoints in a digital era. Popular ride services such as Uber have been lauded for bringing much needed transportation services that are superior to expensive taxis or unpleasant or inaccessible public transit:

In five years, the app economy will be worth $\$ 6.3$ trillion, up from $\$ 1.3$ trillion last year, according to a report released today by app measurement company App Annie.

Mobile commerce's huge footprint includes purchases through retail behemoths like Amazon and Alibaba, as well as paying for services such as Uber rides or travel booked through a travel app - basically any monetary transaction through an app that holds your credit information. The assumption also relies on the continued transition from in-person purchases to ones done through apps. (Molla 2017)

While these companies are indeed immensely popular, questions remain as to just how much of a problem-solving panacea the apps they produce actually herald and to what extent their 'disruption' breaks more than it fixes. Especially because Uber ride prices are artificially low for the moment while subsidized by investors in these initial stages (Smith 2016), unlike taxicabs.

A lack of labor regulation and initial subsidization from investors may present a significant savings to the user, but one may ask if these practices are sustainable as a 'gig economy' (Sundarajaran 2015). Adding to the temporary nature of this work are plans to switch to driverless vehicles. So, structuring one's life around stringing together multiple gigs (that have little protection and no benefits) all to assist in the obsolescence of one's trade, may prove devastating to labor forces. At present, a handful of organizations largely unfettered by regulations now broker the labor of an increasingly contingent workforce. Simultaneously, these same companies fight for control in a new frontier of information and communication technologies (McAlister 2016). In this context, how are we to consider and act upon the issue of a digitally mediated wealth divide, or, as Greenfield (2015) puts it, a 'socially corrosive mobility'?

The popularity of rideshare services like Uber has created an inaccurate sense that public transit has become superfluous (Millsap 2016). However, as many studies (LeBlanc 2018) have suggested, ride hailing services are not a substitute for public transit. Public services are mandated to be accessible in many ways Uber is still not, such as to: a) underserved communities b) the vulnerable (physically or otherwise) c) those without credit cards or smartphones. Publicly accessible transportation, especially in the US context in which Uber originated, is already embattled, and ride hailing services have served as a rationale to choke 
off resources to publicly accessible services (Jerch, Kahn \& Li 2016). As instances of the false equivalency between ride hailing and public transportation systems grow, support for public transportation systems dwindles and history has shown that once support for public infrastructures crumble, they are that much more difficult to revive, revitalize, and reinstate. From a social justice perspective, divesting in public transit because needs are being met for a certain section of relatively affluent individuals promises further inequality with respect to mobility and the benefits therein. Moreover, widespread reliance on private vehicles has done nothing to aid traffic congestion and efficiency.

As a result of over three years of ongoing research and analysis, this article is a comprehensive assessment of a number of social issues facing the integration of practices both signified and enacted in an economy driven by apps such as Uber. We are at a watershed moment of policymaking at a time when digital divides are being simultaneously negotiated and relitigated. This environmental scan covers many issues that are currently in flux and evolving. This discussion focuses primarily on the U.S. context, given that the company and its practices originate from Silicon Valley and are thoroughly embedded in the nation's labor ideologies and debates regarding corporate libertarianism, privatization, and regulation.

In a relatively short time, consumer knowledge and sentiment about Uber and what it has come to mean has evolved and grown. In this case, the consumer is just one of the stakeholder groups woven into the mainstream discussion. It bears some reflexive examination that the enduser groups serve as data points at the end of iterative cycles of development. That is, public stakeholder groups are largely the guinea pigs of this form of development, with the product unleashed in the world in many versions that may be shaped all too late in the process by ethical concerns. More pertinent for the purposes of discussing the ethical issues, one must start by mapping out the current situation, who is involved, and the social issues that have emerged in the stakeholder groups discussed here.

The discussion of policy implications, priorities, and a roadmap forward is essential for focusing the efforts to bring much needed attention to the social justice, media justice, and ethical nuances of the digital divide. Due to the much lauded 'disruption' this genre of platform services has now lent to the everyday communication of goods, services, and people, entire systems have gone unchecked and unfettered. The policy regimes are simply not in place, nor are tax structures, labor regulations, and assessments of impact on public infrastructures. When, however, a mode of transportation transitions from a novelty to an everyday mainstay, becoming woven into the general economy, decision-makers have a responsibility to ensure that the resulting disruption is as ethical and just as possible.

Ideologically, there is a point of tension between governmental/regulatory bodies, 'innovators' (Lehdonvirta 2015), and users. Stakeholders of all stripes are scrambling to keep up with the pace and problematics of digital innovations and an inclusive critical dialog on app-driven services has yet to become a priority. An analytical framework from a social justice perspective stands to catalyze action on a number of pervasive issues surrounding digital ethics and policy. 
This paper will discuss a number of ways in which current ride hailing practices are problematic and amount to a race to the bottom. How do these specific practices, encompassing issues of labor, the digital divide, and public infrastructures, contribute to the increasing corrosion of the social contract if left unfettered? For the standing reserve of labor that enable ride hailing services, do current practices promote upward mobility or are they merely enriching the brokers of these services?:

According to analysis by experts at MIT's Center for Energy and Environmental Policy Research (CEEPR), Uber and Lyft drivers make a median profit of $\$ 8.55$ an hour before taxes, once insurance, maintenance, repairs, and other costs are factored in. That means 54 percent of drivers earn less than their state's minimum wage and nearly one in 10 actually lose money on the job.

A first draft of MIT's research earlier this month mistakenly set Uber and Lyft drivers' median profit at $\$ 3.37$, but that number was heavily criticized by both Uber executives and economists as "deeply flawed." As a result, the figure was revised up by Zoepf, and he promised a "thorough revision" of the paper. The new analysis was released on Monday and included the median $\$ 8.55$ per hour figure.

"Regardless of the exact percentage, the fact that a significant portion of Uber and Lyft drivers are making less than minimum wage is a serious problem that needs to be addressed," Moira Muntz, of the Independent Drivers Guild, which advocates for app-drivers in New York City, told ThinkProgress. "Even in New York City, where most drivers are full time, Uber and Lyft drivers are making less than minimum wage after expenses. As a result drivers are working longer and longer shifts and the economic desperation is palpable." (Barnes 2018)

Such disparities are not unusual--think of the Industrial Revolution. However, as Vincent Mosco and Catherine McKercher (2009) have written, the information/knowledge economy has not yet experienced a labor revolt akin to that of the Industrial Revolution. Ride hailing services are a prime example. On the service side, drivers typically earn less than the minimum wage. On the user side, issues of gender and race result in the marginalization of vulnerable groups. On the platform side, too, software engineers are subject to sexism and racism.

\section{Building the boat while sailing}

This paper contributes an analysis of the digital economic landscape, with an articulation of issues and stakeholders specific to the digital divide in the form of media justice, social justice, and ethics. Because the phenomena is emergent and amorphous, it is even more important to highlight key issues, talking points, and recommendations so that we may prioritize our efforts and direct our energies appropriately according to the interdependent stakeholder relationships.

A study of ride hailing apps is very much in the spirit of Schutz's (2012) painting 'Building the boat while sailing.' Policy must change and adapt to new revelations about the ride hailing companies, their services, and daily changes to their impact on the broader public. The focus of this paper is to boil down the baseline elements of how Uber has worked as a concept, its attendant social issues, and where that leaves policy and the public good at the end of the day. 


\title{
Stakeholder groups under discussion
}

This article examines the social issues and policy implications arising from the consideration of five primary stakeholder groups:

- Drivers

- Developers

- Riders

- Corporation (Uber)

- Government (regulators, infrastructure)

The intended audience of this paper, which derived from a presentation at the Conference on the Partnership for Progress on the Digital Divide, includes researchers and policymakers at the forefront of social issues facing our world. This paper covers not only emergent phenomena in a digital age, but also the specific policy implications of what this digital era presents in terms of affordances, constraints, strengths, weaknesses, opportunities, and threats.

\section{Digital divide (media justice)}

\begin{abstract}
For a slim shard of the world's favored, a bleak prosperity prevails... Their days are largely given over to the pleasures of friendship, conviviality and hard work; they arrange their brunches, vacations, hookups, gigs and pregnancies via app, and get around all but effortlessly, still delighted that the new autonomous Ubers relieve them even of the hassle of interacting with a driver. (Greenfield 2017, pp. 293-294)
\end{abstract}

There are a number of ways an uncritical and unconditional acceptance of the Uber service may exacerbate a digital divide. This section primarily focuses on the rider stakeholder group to discuss the needs that have not been addressed in already marginalized populations of the imagined end-users. The populations that are most vulnerable in terms of the digital divide include the geographically under-resourced and underserved, the young, elderly, and physically challenged, and undocumented persons.

Possible approaches to better remedying and serving these populations are discussed also in the policy implications section, covering ways that we might design our future to be inclusive, equitable, and just.

\section{The young, elderly, and physically challenged}

There is little incentive for a private company such as Uber and those who drive for it to serve those with limited income or mobility (Mirani 2014). For a large proportion of the population, driving is simply not an option due to age and/or physical ability. Around the world, a public transit mandate is essential, as the elderly and physically challenged often rely on transportation services that accommodate wheelchairs and have other vehicular enhancements. For those who are in need of safe, consistent transportation, but may find themselves mobility-impaired, public infrastructure is an essential and ethical service for a democratic society. 
Children and their caretakers are also underserved by ride hailing apps. Youths under 18 , for example, are not permitted to ride unaccompanied on Lyft and Uber at all. For parents with infants, whereas a bus may be mandated to accommodate strollers, a random car hailed on any given day may not even have a safety belt of adequate length to accommodate a car seat. In a problematic attempt to address this particular issue, Uber has provided the Uber Car Seat option, which, '...provides uberX vehicles equipped with a car seat... A \$10 surcharge is added to uberX pricing for Uber Car Seat trips. A child is too big at 48 lbs. or 52 inches' (Uber Help n.d.). This option is further restricted to children over 12 months of age. Even for those families who do meet all requirements, the per trip surcharge would render this service cost prohibitive to many.

\section{Under-resourced and underserved}

In an era of digital redlining, lack of access to devices and technical specifications also implicate geographies of exclusion. In addition to the cost of the ride, smartphones and their plans are themselves costly. A transportation service that requires riders to use both a mobile computing device and credit card presents a convenience, but is also exclusionary.

Even so, the issues are not as easily remedied as simply putting a mobile device into every hand. Much like the One Laptop Per Child movement that oscillated between vision and reality (Kraemer et al 2009), the issue at hand is not just about access to standalone devices. Rather, devices are merely gateways or 'dummy terminals' that provide access to the truly valuable network, society, and broader webs of significance. Having access to smartphones, credit, and credit cards as a baseline requirement to participation in the platform economy not only exacerbates an already existing digital divide; it creates new fissures in the physical social fabric. Point to point travel that is private already contributes to urban decay and lack of everyday engagement and inclusion, as is well documented in Greenfield (2017).

Moreover, the mobility of those who do not live centrally, or in less desirable areas, is at the behest of driver availability and willingness. This vulnerability may be regarded as a type of digital redlining. A rider can be left without a ride if they do not live within desired range/location. This could exacerbate the bleeding out of marginalized population zones, further entrenching privilege and contributing to the increasing polarization of wealth we are seeing even in Silicon Valley's own increasingly dystopian landscape. Ride hailing services cannot be a replacement for public transit.

\section{Public infrastructures: towards social justice and away from corrosive mobility}

In the context of a discussion about Google self-driven cars, Ethan Zuckerman questions the US' problem with public goods and muses: 


\begin{abstract}
How did we reach a state in America where highly speculative technologies, backed by private companies, are seen as a plausible future while routine, ordinary technologies backed by governments are seen as unrealistic and impossible?

...we don't have influence over what services Google does and doesn't provide, and our investment is an investment of attention as recipients of ads, not taxation. (Zuckerman 2013)
\end{abstract}

Reflecting the hegemony of private transportation, a working paper by the National Bureau of Economic Research (NBER) (Jerch, Kahn \& Li 2016) argues that privatizing public bus services could save $\$ 5.7$ billion a year in the United States. Studies espousing the privatization of public services as a cost cutting measure also point the finger at the wastefulness of public services, serving to discredit unions in the process as well (Millsap 2016). The rhetoric is eerily familiar and effectively advocates starving the public system, then criticizing that public transit is broken, which ultimately results in further funding cuts. This is damaging rhetoric because rather than individuals acting in a vacuum, corporate libertarian discourse (Mosco 2014) does not acknowledge how we are a networked society (Castells 2009) and actually a web of interdependencies, especially for transportation and mobility.

Taxes pay for roads and other public goods that Uber uses. Uber avoids contributing to tax regimes around the world, yet diminishes popular support for local regular jobs and revenue systems through its service. As the company has said, 'Our corporate tax structure is probably the least innovative thing about Uber. It's the standard approach adopted by most multinational companies'(O'Keefe \& Jones 2015).

What pro-privatization studies fail to convey are the interdependencies between public services such as transit, the preservation of a functional national workforce, and the construction of the very roads upon which Uber cars drive. Additionally, mass public transit does what individual passenger vehicles cannot do, which is relieve congestion by taking cars off the road (LeBlanc 2018).

\title{
Examining the Full cost
}

The Digital Sublime can be very seductive (Mosco 2004), especially if it comes with the promise of saving billions of dollars, which ostensibly transmutes into less need for taxpayer money overall, and subsequently tax cuts followed by full privatization. However, policy makers have an obligation to examine the full cost of transactions for the public interest. This entails more rigorous research and less reliance on convenient numbers. The cost cutting rationale espoused by those who would advocate privatizing public transit, is extremely short term.

A better approach to analyzing the myriad factors impacting public services would be Squires' (2013, p. 104) concept of 'full cost' economics, which takes into account not only the costs to a given firm (internal), but also the social and environmental costs (external):

As an equation, if the full cost can be quantified, it is expressed quite simply as follows:

- $\quad$ Full cost $=$ internal cost (firm) + external cost (social and environmental) (Squires 2013, p. 104) 
When discussing transportation, it is essential to weigh the total costs because the environment and landscapes are implicated. As a software company, there is everything to gain by avoiding public accountability, but this lack of social reciprocity is the digital age equivalent of an extraction industry centered around raw materials and pillaging of the earth. At the end of the day, the private transportation model for everyday uses, especially commuting, do nothing to take cars off the road and relieve congestion. In the Marshall McLuhan sense regarding Laws of Media (1988), adding cars to further clog up roads would be a classic case of reversal for what might otherwise be lauded as an innovation.

\section{In sickness and Uber Health}

A recent development marketed as an attempt to address the dire state of affairs in the US health system has been branded as Uber Health. This initiative seeks to formalize the preexisting practice of taking an Uber to the hospital in the role of an ambulance, sometimes through explicit partnerships with care providers (O'Donovan 2018). There are many reasons for and problems with why riders already use Uber to get to and from hospitals and other medical providers in the United States. What is already occurring is that people call 911 for nonemergencies because they do not have health insurance. In addition to the inefficiency of that practice, it speaks to the already stratified state of access to healthcare.

Taking an ambulance to the hospital may cost hundreds of dollars, and possibly over $\$ 1000$. Considering how cost prohibitive medical assistance can be, this factor causes many to instead take matters into their own hands and seek out lower cost alternatives, such as an Uber or taxi.

As with regular Uber, Uber Health is a delegation of all risks to the drivers and riders.

Elsewhere, governmental health systems that are able to bargain with providers achieve an economy of scale in terms of costs across the board. Also, the drivers themselves (i.e. paramedics/ambulance drivers) are trained and skilled in the provision of medical attention.

While this article cannot be a comprehensive critique of the inefficiencies in the US health system as a whole, it is important to discuss some cursory problematics of Uber Health at first glance.

\section{Lack of driver training and preparation}

In order to become an Uber driver, there is a low bar to entry (be over 21 years old, pass a state and federal background check, have 1 year of driving experience) (Uber.jobs n.d.). Once on the job, any number of situations may present themselves due to the random nature of those who require rides from one location to another. There is a dire lack of training for this increasing population of precariously 'employed' drivers who do not have any classification besides being independent contractors. The driver's own vehicles are not held to any reliable standard, use the driver's own insurance, and the condition of the vehicle itself varies vastly. As far as licensed taxi drivers go, they themselves are barely equipped to handle the variation in clientele in terms of training and preparation, nevermind lay people who end up driving for Uber. Indeed, the lack 
of driver training and preparation are indicative of the lack of long term plans for human drivers in general. Looking into the future, the human drivers are merely a stop gap measure in anticipation of automated (driverless) cars.

Liability issues also abound. Considering the diverse range of people a rideshare driver may encounter at any given point, there is relatively little training and preparation to become an Uber driver. Moreover, drivers are using their own personal car insurance to operate rideshare vehicles in a decidedly commercial fashion. As the rideshare company can claim to act merely as a type of 'matchmaking' app, this arrangement means that all of the risks are undertaken by the driver and rider. In at least one case, an injured UberX driver was left to assume the consequences of a major car accident after alleging that Uber had assured him of insurance protection (Lieberman 2015).

\section{The Gig Economy as symptom of kleptocracy}

\section{The myth of the freelancer as freedom}

'Uber, but for [food, shelter, sex...]' has become part of the regular lexicon. Drawing attention to the social, economic, and environmental damage of these kleptocratic practices casts a pall on the promise of a bright, utopian meritocratic future where we supposedly all win and all boats rise. Calo and Rosenblat (2017) with their critique aptly named, 'The Taking Economy: Uber, Information, and Power,' join an increasingly large chorus of analyses that inform policymaking through legal and ethical concerns of new and as of yet largely unregulated industrial practices. The tension between entrenched industries and new 'disruptive' upstarts have shown up headlines around the world. The U.S. audience appreciates a classic David and Goliath narrative, even in stories like how Uber and Lyft are 'destroying Chicago's cab drivers' (Ciolli 2017). However, the narrative of rideshare drivers taking on entrenched taxi cartels is too facile and unidirectional. In contrast, the desperation was palpable in the case of one New York taxi driver (Bellafante 2018) who committed suicide to demonstrate how ride hailing services have financially devastated and disrupted their livelihoods.

A particular--though not at all rare--story is of people who have made the decision to drive for Uber due to a life-altering event such as injury, layoff, retirement, or unspecified debts. That life event may not have not been conducive to holding a regular full-time job with benefits, including any form of health coverage in the United States. Moreover, for those who do have health insurance, coverage does not guarantee access to affordable health care, as the deductible model almost entirely ensures that a person seeking even rudimentary treatment will need to pay hundreds if not thousands of dollars up front before coverage becomes apparent. This is a troubling state of affairs, given that numerous households are potentially one accident away from bankruptcy.

Where this issue intertwines with the gig economy is the myth of the freelancer who is ultimately liberated by the flexibility afforded by being an independent contractor, as opposed to an 
employee restricted by the prescripts of a single employer. The devastating narratives of actual wages hit a fever pitch in early 2018 with the publication of data stating that the hourly wage of an Uber/Lyft driver amounted to \$3.37/hour (Levin 2018b). After a critical response from the Chief Economic Offer at Uber about the widely publicized data, the author of the MIT study revised their analysis to a wage range of $\$ 8.55-\$ 10 /$ hour (Winick 2018). However, that figure is still below minimum wage and is immensely variable considering tips and local costs of living. Numerous studies continue to show that more often than not, the worker in this case is in the position of desperately cobbling together a living wage with these myriad flexi-jobs to stay afloat. One must ask if this is the freedom largely envisioned, and who ultimately benefits from the perpetuation of this myth.

Despite and likely because of the proliferation of precarious labor, there have been disparate attempts to unionize rideshare drivers, as in the case of Seattle (Isaac, Wingfield \& Scheiber 2015), and recently Millennials have been showing an increased interest in the formation of unions after a long-term decline in workforce unionization (Chen 2018). Scholz (2017) advocates 'platform cooperatives', which work with the platform and worker-owned cooperatives to 'rethink unions, and build a better future of work.' The questions in his book, Uberworked and Underpaid, remain in terms of how digital labor may be regulated, with much dependent upon how collective organizing at the local and global levels take place.

Indeed, the precariat is not progress, and the struggles this large, multi-sector workforce face are something akin to those encountered in the adjunctification of the professoriate, where $70 \%$ of college professors are contingent labor (American Association of University Professors n.d.). As with adjunct professors, there is a common misconception that these workers are merely topping up a base income earned elsewhere, so they do not require any livable wage or benefits in the contingent labor they are performing. While there is likely a small minority that fits the stereotypical description, the data on these labor forces show that most are stitching together a basic income through many precarious jobs.

\section{A temporary stop-off on the way to autonomous vehicles}

These increasingly neo-feudal conditions are allowed to continue under the rationalization of the 'free market', in favor of the celebratory discourse of the 'Gig economy'. The embodied nature of its workers who require food, shelter, health care, and a living wage are only a temporary inconvenience on the way to the utopian imaginary of driverless cars dotting our sky.

Kai-Fu Lee (2018) predicts that autonomous vehicles will replace human-driven cars in about 15-20 years in the US and even less time in China if they continue advancing in AI research as they have been to date. He also cautions that we are not ready for the massive societal upheavals on the way to that vision. Due to the inconsistencies in law from state to state, Uber has already been experimenting with autonomous vehicles (cars and trucks) in various locations with minimal hindrance (Bonnington 2018). 
The long game is to starve out any real alternatives to these services, such as licensed taxis and public transit, all the while using big data/machine learning to create fully automated routes. Eventually, the vision is for driverless cars. Then where will the drivers be, who have leveraged themselves in the meantime?

\section{Ethical issues and Policy Implications}

Indicative of the app-centered media age in which we live, hardly a day goes by in which Uber has not made headlines in the mainstream media. The ethical issues have been challenging to wrangle, due to the number of parties implicated and lack of precedent. Were it not for the sheer number of ethical grievances coming to light in recent years, the demand for a comprehensive analysis of the issues at stake would not have the same urgency that it does today. This section identifies some of the major ethical issues that intersect with multiple stakeholders discussed in this paper, which each deserve their own analyses, critiques, and action going forward.

Advocating for a focus on the ethical dilemmas associated with the Uber service sets the stage for a broader critique of the platform/gig economies and their lack of regard for the social good. It is particularly challenging, because a service such as Uber enjoys widespread popularity while also being immensely problematic for those with the least power and mobility. For those who do have the decision-making power, it is important to make instrumental decisions that are not only popular, but also ethical.

With a company as powerful and pervasive as Uber, it is already difficult to operate without touching or being touched by the organization and its practices. As Uber transitions from being a company to an institution, and moving ever closer towards fulfilling the role of a utility or essential service, it is more important than ever to make sure that people who hold the keys to power in law and policy do not capitulate too easily to the interests of a private corporation that is not beholden to a duty to serve the public.

The ethical challenges here largely touch upon the predator/prey dichotomy that have been symptomatic of the broader culture in which Uber has been developed. The cases surrounding gender-based violence for riders (Levin 2018a), drivers (Levin 2017), and Uber's developers (Fowler 2017); racist practices by drivers (Newcomer 2016); systemic sexism and racism in the company still coming to light (Ge et al. 2017); and privacy issues arising from unethical treatment of user data (Hill 2014)--all speak to the profoundly troubling social issues that continue to plague the company. The convergence of these pressure points serve to highlight the position of trust inherent for a service like Uber to function and its effect on the vulnerable, underscoring the need for ethical oversight. Without adequate measures to curtail and critique these designs while they are being conceived, we will only encounter these problems out 'in the wild', at which point it is often too late to put the proverbial genie back in the bottle, especially concerning issues of data and privacy. 


\section{Designing the future}

When we look at ethics, social justice, diversity and inclusivity, the effort to etch those facets into policy must include both company culture and their creations. A service like Uber serves to structure and restructure the way we do things like communicate and get from point $A$ to point B. Gender issues, as in many companies, have presented dysfunction in both the rank and file as well as the 'product' produced. The argument goes that without diversity from the start of the product cycle, from concept through to implementation and maintenance, the product (which is already inscribed with the norms and values of the designers and engineers), will reflect similar biases. What better way to show what a society values than how it enables the mobility of different people and their various bodies?

Social media movements like \#deleteUBER only individualize social issues and put the onus on the rider to decide whether or not to use the service. Solutions that address the roots of systemic issues need to come into play. In a networked society full of interdependencies, the solution has never been to boycott. The recommendations here refer to the ethical considerations forwarded in this paper and serve to open up dialogue to further discuss the persistent issues facing a precarious future.

One major change would be to treat Uber like a taxi company as opposed to a web service. In December 2017, such a ruling was made in the E.U. (May 2017). Another direction to pursue would be to demand stronger partnerships with the municipalities in which rideshare companies operate, in order to work towards linking public infrastructure with ride hailing operations rather than competing with them. The methods of payment must be accessible and not serve to exacerbate further inequalities in wealth and mobility. Related to mobility, the use of surge pricing according to demand for transportation services is harmful and predatory, and must be brought under control or eliminated altogether. Protections for public infrastructure, increased (not decreased) investment in public transportation through data gathering, and channeling revenue to socialized services through tariffs would cause ride cost to resemble taxi costs more closely. In the case of Uber Health, measures taken to make the cost of medically trained personnel available would also appropriately reflect costs. In essence, localities where Uber benefits must themselves more explicitly benefit through increased partnerships and regulatory policy.

\section{Conclusion}

As a reflection deriving from the conference on the Partnership for Progress on the Digital Divide, this paper is a necessary opportunity to think through whether we are headed in the right, just, and ethical direction. For decision makers and those attempting to formulate ethical policies around ride hailing services, the task ahead is formidable. Corrosiveness, by its very nature, is not readily apparent. Stewardship is not immediately recognized, and perhaps never obviously rewarded. However, ethical practices must be built into the DNA of any organization, permeating its practices, personnel, and products. 
With Uber rapidly becoming part of everyday life and a regular part of the public lexicon, this paper was a comprehensive examination of the ethical dilemmas that already manifest in the creation of a digital divide, their implications for public infrastructures, and the Gig Economy as a symptom of kleptocracy rather than liberation. The approach is multi-pronged with many interlocking pieces when examining communication technology from media justice, social justice, and ethics perspectives.

Who is predator and prey in this gig economy of the Wild West? In its most ideal form, the purpose of policy and regulation is to make things more regular, civilized, orderly, and peaceful. Perhaps our practices may even be kinder in an otherwise cruel world. Despite all the technological progress occurring every day, one must ask what the ultimate purpose of innovation and advancement should be? If we are able to draw attention to how things are getting worse for those already most vulnerable, should we not attempt to mobilize in order to bring those harms to a halt? The situation is evolving, but this article asks the primary question, given the issues and people at stake, is this the society we want?

Much like getting to choose the paint color for a car already in the parking lot, true change cannot come as a result of consumer choice. It is a common deflection to place the onus on comparatively powerless individuals when discussing systemic issues. The choice should not be between Uber or Lyft, but rather between a healthy society or a toxic one. We have the opportunity at this juncture to ask for the kind of society we really want. This paper is a critique of the fundamental norms and values driving what amounts to a race to the bottom. The optimistic kernel to take from this exposition is that this does not have to be our destination.

\section{References}

American Association of University Professors n.d., Background Facts on Contingent Faculty, viewed 17 March 2018, https://www.aaup.org/issues/contingency/background-facts

Barnes, L 2018, 'New study reveals just how little Uber drivers make', ThinkProgress, 6 March, viewed 17 March 2018, https://thinkprogress.org/uber-drivers-often-make-less-than-minimumwage-according-to-new-study-912d388c3c82/

Bellafante, G 2018, 'A Driver's Suicide Reveals the Dark Side of the Gig Economy', The New York Times, 6 February, viewed 17 March 2018, https://www.nytimes.com/2018/02/06/nyregion/livery-driver-taxi-uber.html

Bonnington, C 2018, 'Uber's Secretive Self-Driving Trucks Could Undermine the Industry', Slate, 7 March, viewed 18 March 2018, https://slate.com/technology/2018/03/uber-self-drivingtruck-efforts-need-more-transparency.html 
Calo, R \& Rosenblat, A 2017, 'THE TAKING ECONOMY: UBER, INFORMATION, AND POWER', Columbia Law Review, vol. 117, no. 6, viewed 17 March 2018, http://columbialawreview.org/content/the-taking-economy-uber-information-and-power/

Castells, M 2009, The Rise of the Network Society, With a New Preface The Information Age: Economy, Society, and Culture Volume I 2nd ed., Wiley, Hoboken.

Chen, M 2018, 'Millennials Are Keeping Unions Alive', The Nation, 5 February, viewed 17 March 2018, https://www.thenation.com/article/millennials-are-keeping-unions-alive/

Ciolli, J 2017, 'Uber and Lyft are destroying Chicago's cab drivers', Business Insider, 7 June, viewed 18 March 2018, http://www.businessinsider.com/uber-and-lyft-are-destroying-chicagoscab-drivers-2017-6

Fowler, S 2017, 'Reflecting On One Very, Very Strange Year At Uber', Blog - Susan Fowler, web log post, 19 February, viewed 18 March 2018, https://www.susanifowler.com/blog/2017/2/19/reflecting-on-one-very-strange-year-at-uber

Greenfield, A 2015, 'Uber, or: The technics and politics of socially corrosive mobility', Adam Greenfield's Speedbird, web log post, 29 June, viewed 17 March 2018, https://speedbird.wordpress.com/2015/06/29/uber-or-the-technics-and-politics-of-sociallycorrosive-mobility/

Greenfield, A 2017, Radical technologies : the design of everyday life, Verso, Brooklyn.

Hill, K 2014, '“God View”: Uber Allegedly Stalked Users For Party-Goers' Viewing Pleasure (Updated)', Forbes, 3 October, viewed 17 March 2018, https://www.forbes.com/sites/kashmirhill/2014/10/03/god-view-uber-allegedly-stalked-users-forparty-goers-viewing-pleasure/\#5bedd1ae3141

Isaac, M, Wingfield, N \& Scheiber, N 2015, 'Seattle Considers Measure to Let Uber and Lyft Drivers Unionize', The New York Times, 13 December, viewed 17 March 2018, https://www.nytimes.com/2015/12/14/technology/seattle-considers-measure-to-let-uber-and-lyftdrivers-unionize.html

Jerch, R, Kahn, M \& Li S 2016, 'Efficient Local Government Service Provision: the Role of Privatization and Public Sector Unions', NBER Working Paper, No. 22088, doi: 10.3386/w22088

Kraemer, K, Dedrick, J \& Sharma, P 2009, 'One laptop per child: vision vs. reality', Communications of the ACM, vol. 52, no. 6, pp.66-73.

LeBlanc, S 2018, 'Studies are increasingly clear: Uber, Lyft congest cities', The Associated Press, 25 February, viewed 17 March 2018, https://apnews.com/e47ebfaa1b184130984e2f3501bd125d 
Lehdonvirta, V 2015, 'Uber and airbnb make the rules now — but to whose benefit?', The Policy and Internet Blog, web log post, 27 July, viewed 17 March 2018, http://blogs.oii.ox.ac.uk/policy/uber-and-airbnb-make-the-rules-now-but-to-whose-benefit/

Lee, K 2018, 'Tech companies should stop pretending Al won't destroy jobs', MIT Technology Review, 21 February, viewed 18 March 2018, https://www.technologyreview.com/s/610298/tech-companies-should-stop-pretending-ai-wontdestroy-jobs/

Levin, S 2018, 'Uber accused of silencing women who claim sexual assault by drivers', The Guardian, 15 March, viewed 18 March 2018, https://www.theguardian.com/technology/2018/mar/15/uber-class-action-lawsuit-sexual-assaultrape-arbitration

Levin, S 2018, 'Uber drivers often make below minimum wage, report finds', The Guardian, 5 March, viewed 17 March 2018, https://www.theguardian.com/technology/2018/mar/01/uber-lyftdriver-wages-median-report

Levin, S 2017, 'Female Uber driver says company did nothing after passengers assaulted her', The Guardian, 1 May, viewed 18 March 2018, https://www.theguardian.com/technology/2017/may/01/uber-sexual-assault-allegations-femaledrivers-san-diego

Lieberman, C 2015, 'UberX driver says he will take legal action against company after major crash', Global News, 18 August, viewed 17 March 2018, https://globalnews.ca/news/2172234/uberx-driver-says-he-will-take-legal-action-after-majorcrash-in-toronto/

May, K 2017, 'Uber told it's a taxi company, not a web service', PhocusWire, 20 December, viewed 17 March 2018, https://www.phocuswire.com/Uber-loses-EU-taxi-ruling

McAlister, M 2016, 'Transportation v communication: the fight for control of the new frontiers', The Guardian, 24 May, viewed 17 March 2018, https://www.theguardian.com/medianetwork/2016/may/24/google-facebook-self-driving-car-virtual-reality-information-distribution

McLuhan, M \& McLuhan, E 1988, Laws of media : the new science, University of Toronto Press, Toronto.

Mirani, L 2014, 'The secret to the Uber economy is wealth inequality', Quartz, 16 December, viewed 17 March 2018, https://qz.com/312537/the-secret-to-the-uber-economy-is-wealthinequality/ 
Molla, R 2017, 'The app economy will be worth \$6 trillion in five years thanks to mobile commerce', recode, 27 June, viewed 17 March 2018, https://www.recode.net/2017/6/27/15876294/app-economy-6-trillion-mobile-commerce-amazonalibaba

Millsap, A 2016, 'Privatizing Public Transit Lowers Costs And Saves Cities Money', Forbes, 20 April, viewed 17 March 2018, https://www.forbes.com/sites/adammillsap/2016/04/20/privatizingpublic-transit-lowers-costs-and-saves-cities-money/\#1f978af422e6

Mosco, V 2004, The digital sublime myth, power, and cyberspace, MIT Press, Cambridge.

Mosco, V 2014, To the cloud : big data in a turbulent world, Paradigm Publishers, Boulder.

Mosco, V \& McKercher, C 2009, The Laboring of Communication: Will Knowledge Workers of the World Unite?, Lexington Books, Lanham.

Newcomer, E 2016, 'Study Finds Racial Discrimination by Uber and Lyft Drivers', Bloomberg Technology, 31 October, viewed 18 March 2018, https://www.bloomberg.com/news/articles/2016-10-31/study-finds-racial-discrimination-by-uberand-lyft-drivers

Noble, S 2018, Algorithms of Oppression: How Search Engines Reinforce Racism, NYU Press, New York.

O'Donovan, C 2018, 'People Are Using Ubers As Ambulances - And Drivers Hate It', BuzzFeed News, 26 February, viewed 17 March 2018, https://www.buzzfeed.com/carolineodonovan/taking-uber-lyft-emergency-room-legalliabilities?utm term=.ekYPJ3Bqw\#.dpOK5WQzv

O'Keefe, B \& Jones, M 2015, 'How Uber plays the tax shell game', Fortune, 22 October, viewed 18 March 2018,http://fortune.com/2015/10/22/uber-tax-shell/

Scholz, T 2017, Uberworked and underpaid : how workers are disrupting the digital economy, Polity Press, Cambridge.

Schutz, D 2012, Building the Boat While Sailing, online image, viewed 17 March 2018, http://www.petzel.com/artists/dana-schutz/featured-works\#43

Smith, Y 2016, 'Can Uber Ever Deliver? Part One - Understanding Uber's Bleak Operating Economics', Naked Capitalism, 30 November, viewed 17 March 2018, https://www.nakedcapitalism.com/2016/11/can-uber-ever-deliver-part-one-understanding-ubersbleak-operating-economics.html 
Sundarajaran, A 2015, 'The "gig economy" is coming. What will it mean for work?', The Guardian, 25 July, viewed 17 March 2018,

https://www.theguardian.com/commentisfree/2015/jul/26/will-we-get-by-gig-economy

Squires, G 2013, Urban and Environmental Economics: An Introduction, Routledge, New York.

Uber.jobs n.d., Requirements, viewed 18 March 2018, https://uber.jobs/

Uber Help n.d., Uber Car Seat, viewed 17 March 2018, https://help.uber.com/h/3abcbae1-132b42a9-8277-0dab00fa3879

Winick, E 2018, 'Maybe Uber and Lyft drivers *can* make a living', MIT Technology Review The Download, 6 March, viewed 17 March 2018, https://www.technologyreview.com/thedownload/610428/maybe-uber-and-lyft-drivers-can-make-a-living/

Zuckerman, E 2013, 'Google cars versus public transit: the US's problem with public goods', My heart's in Accra, web log post, 15 October, viewed 17 March 2018, http://www.ethanzuckerman.com/blog/2013/10/15/google-cars-versus-public-transit-the-ussproblem-with-public-goods/ 